\begin{tabular}{rr} 
çağdaş & Yaratıcı Drama Dergisi 2015, 10(1), 91-102 \\
drama & www.yader.org \\
\hline
\end{tabular}

\title{
Lise Öğrencilerinde Yaratıcı Drama Yöntemiyle Siber Zorbalık Hakkında Duyarlılık Oluşturma
}

\author{
Gamze Baştak ${ }^{1}$ \\ Hasan Hüseyin Altınova ${ }^{2}$
}

\begin{tabular}{|c|c|}
\hline Makale Bilgisi & $\ddot{\mathbf{O z}}$ \\
\hline DOI: 10.21612/yader.2015.009 & Bu araştırma ile lise onuncu sınıf ögrencilerinde yaratıcı drama yöntemiyle siber \\
\hline $\begin{array}{l}\text { Anahtar Sözcükler } \\
\text { Siber zorbalık } \\
\text { Yaratıcı drama } \\
\text { Lise ögrencileri }\end{array}$ & $\begin{array}{l}\text { zorbalık hakkında farkındalık oluşturulması amaçlanmıştır. Araştırma, kontrol } \\
\text { gruplu ön test-son test modelinin kullanıldı̆̆ deneysel bir çalışmadır. Araştırmanın } \\
\text { çalışma grubunu, Gazi Çiftliği Anadolu Lisesi 2013-2014 öğretim yılı güz ve bahar } \\
\text { döneminde eğitim gören } 10 \text { sınıf öğrencileri oluşturmuştur. Deney grubunda } 16 \\
\text { kontrol grubunda } 19 \text { öğrenci yer almıştır. Araştırmada veri toplama aracı olarak, } \\
\text { Siber Zorbalığa Illişkin Duyarlılık Ölçeği (SBDÖ) kullanılmıştır. Deney ve kontrol } \\
\text { gruplarının toplumsal cinsiyet rolü ve toplumsal cinsiyet algısı düzeyleri arasında } \\
\text { anlamlı bir fark olup olmadığını belirlemek amacıyla, parametrik olmayan analiz } \\
\text { tekniği (Mann-Whitney U ve Wilcoxon testleri) kullanılmıştır. Bulgular, deney } \\
\text { grubunda yapılan drama çalışmasının ögrencilerin siber zorbalığa ilişkin duyarlılık } \\
\text { puanlarını arttırdığı göstermektedir. Elde edilen bulgulardan yola çıkarak yaratıcı } \\
\text { drama yöntemi ile yapılan grup çalışmasının öğrencilerin, siber zorbalık hakkında } \\
\text { farkındalık kazanmasında etkili bir yöntem olduğunu göstermektedir. }\end{array}$ \\
\hline
\end{tabular}

\section{Raising Awareness of Cyber-Bullying among High School Students Using the Creative Drama Method}

\begin{tabular}{l} 
Article Info \\
\hline DOI: $10.21612 /$ yader.2015.009 \\
\hline Keywords \\
Cyber-bullying \\
Creative drama \\
High school students
\end{tabular}

\begin{abstract}
With this study, it was aimed to raise awareness of cyber-bullying among 10thgrade high school students using the creative drama method. The research is an experimental study, in which the pre-test and post-test model with the control group is used. The study group of the research consists of 10th-grade students of Gazi Çiftliği Anatolian High School receiving education during the fall and spring semester of the 2013-2014 academic year. 19 students were included in 16 control groups in the experiment group. The Cyber-Bullying Awareness Scale (CBAS) was used in the study as a data collection tool. The non-parametric analysis technique (Mann-Whitney $U$ and Wilcoxon tests) was used in order to determine whether there was a significant difference between the social gender role and social gender perception levels of the experiment and control groups. The findings show that the drama study carried out in the experiment group increases the students' awareness scores concerning cyber-bullying. The findings obtained show that the group study performed with the creative drama method is an effective method in raising awareness of cyber-bullying among students.
\end{abstract}




\section{Giriş}

"Siber" kelimesi İngilizce "Cyber" kelimesinden uyarlanıp kullanılmaya başlanılan bir kelime olup "Bilgisayar ağlarına ait olan”, "İnternete ait olan”, "Sanal Gerçeklik” manalarına gelmektedir. Siber zorbalık, teknolojinin ilerlemesi ve yaygınlaşmasına koşut olarak son 20 yılda ortaya çıkmıştır. Siber zorbalık kavramı ise ilk kez 2004 yılında Kanadalı eğitimci Bill Belsey tarafından kullanılmışır (Bauman, 2007). Siber zorbalık çeşitli araştırmacılar tarafından çevrimiçi zorbalık, dijital zorbalık, elektronik zorbalık, çevrimiçi zarar verme, sanal zorbalık ve internet zorbalığı gibi kavramlarla adlandırılmıştır (Aktepe, 2013).

Belsey’e (2005) göre, siber zorbalık, bilgi ve iletişim teknolojilerini kullanarak, başkalarına zarar vermek amacıyla bir birey ya da grup tarafindan gerçekleştirilen, kasıtlı tekrarlanan ve düşmanca davranışlardır. Arıcak (2011)'a göre ise siber zorbalık, bilgi ve iletişim teknolojilerini kullanarak bir birey ya da gruba, özel ya da tüzel bir kişiliğe karşı yapılan teknik ya da ilişkisel tarzda zarar verme davranışlarının tümüdür. Eroğlu (2011), siber zorbalığı bir birey veya grubun bilgi ve iletişim teknolojilerini diğer bireylere zarar vermek amaciyla kötü niyetle ve tekrarlayan biçimde kullanması olarak tanımlamaktadır. Tanımlardan da anlaşılacağı gibi herhangi bir eylemin siber zorbalık olarak adlandırılabilmesi için her şeyden önce zarar verme amacı taşıması gerekmektedir. Bunun yanında eylemin sürekli olarak tekrarlanması ve ısrar edici olması da önemli ve öne çıkan özelliklerindendir. Ayrıca eylemin gerçekleştirilmesi aşamasında bilgi ve iletişim teknolojilerinin kullanılıyor olması da gerekmektedir.

Siber zorbalık ile ilgili rollere bakıldığında siber zorba, siber mağdur ve siber zorba/ mağdurdan söz etmek gerekmektedir. Siber zorba, siber zorbalık davranışları sergilerken, siber mağdur, bu türden davranışlara maruz kalmaktadır. Siber zorba/mağdurlar ise daha çok siber zorbalık davranışlarını sergilerken aynı zamanda siber zorbalık davranışlarına maruz kalan kişilerdir (Yaman, Eroğlu ve Peker, 2011).

Kişilik özelliklerine bakıldığında siber zorbaların okul yaşamlarının problemli, ders notlarının düşük, ebeveynleriyle iletişimlerinin yetersiz, bilgisayar kullanma becerilerinin iyi, madde kullanmaya eğilimli oldukları, internet ortamında saldırganca davrandıkları, ön yargı ve öfke ile hareket ettikleri, başkalarının üzerinde baskı kurmak için internet ortamından yararlandıkları, internet ortamında kimliklerini gizleyerek siber zorbalık davranışlarında bulundukları, intikam alma duygusu taşıdıkları, kendilerine fazlasıyla güvendikleri, empati kurabilme becerilerinin düşük ve öz saygılarının son derece yüksek olduğu söylenebilir (Yaman, Eroğlu ve Peker, 2011).

Siber mağdurlar ise öz saygısı düşük, duygusal problemleri olan, madde kullanmaya eğilimli, bilgisayar kullanma becerisi zayıf, okul yaşamları problemli ve siber zorbalığa maruz kaldıklarında kendini koruyamayan kişiliklerdir. Siber mağdurlar, sosyal çevreye uyum sağlamada güçlük çekerler, arkadaş sayıları azdır, arkadaşlık ilişkisinden memnun olmazlar ve sürekli olarak kendilerini mutsuz hissederler (Yaman, Eroğlu ve Peker, 2011).

Siber zorba/mağdurların kişilik özelliklerine bakıldığında ise yine arkadaşlık ilişkilerinin ve ailesiyle olan ilişkilerinin problemli olduğu görülmektedir. Siber zorba/mağdurlar interneti çok fazla kullanmaktadırlar ve interneti kullanma konusunda kendilerini yeterli görmektedirler. Davranış bozukluğu gösteren, alkol ve madde kullanmaya eğilimli, internet ortamında hem siber zorbalık yapan hem de siber zorbalığa maruz kalan siber zorba/mağdurların bilgisayar kullanma becerisi iyi düzeydedir (Yaman, Eroğlu ve Peker, 2011). 
Siber zorbalığın görülme biçimleri araştırmacılara göre yediye ayrılmaktadır (Bamford, 2004; Beran ve Li, 2005; Hines, 2011; Patchin ve Hinduja, 2006; Willard, 2005; 2007). Bunlar:

Online Kavga: İki veya daha fazla kişi arasında meydana gelen, ateşli ve kısa süren, tartışmalardır.

Siber Taciz (Zarar verme): Bir kişiye elektronik posta veya diğer yazılı mesajlaşma araçlarıyla tekrar eden saldırgan mesajların gönderilmesidir.

İftira: Bir kişi hakkında zarar verici, gerçek olmayan kaba söylemleri iletişim araçlarıyla başka kişilere göndermek veya çevrimiçi yayınlamak anlamına gelmektedir.

Taklit (Başka bir kimliğe bürünme): Bir kişinin itibarına zarar verecek, yanlış anlaşılmasına sebep olacak materyalin gönderilmesi veya yayınlanmasında başka birisi gibi davranmak anlamına gelmektedir.

Başkasının Bilgilerini Sanal Ortamda İzinsiz Kullanma: Bir kişi hakkında hassas, özel veya utanç verici bilginin veya görüntülerin halka açık olarak gönderilmesi veya yayınlanması anlamına gelmektedir.

Dışlama: Bir kişiyi çevrimiçi bir gruptan kötülük amaçlı olarak dışlamak anlamına gelmektedir.

Siber Tehdit: Bir bireyin kendisine veya başkalarına zarar vermek istediğini dolaylı veya dolaysız bir şekilde iletişim araçları aracılığıyla ipuçları veya imalar şeklinde paylaşıma sunması olarak tanımlanmaktadır.

Siber zorbalık birçok şekilde yapılabilmektedir. Siber zorbalık davranışlarını gerçekleştiren kişiler birçok iletişim aracından yaralanmaktadır. Siber zorbalık araçları araştırmacılar tarafından çeşitli kategorilere göre sınıflandırılmaktadır (Rogers, 2010; Smith, Mahdavi, Carvalho ve Tippett, 2006). Bunlar:

Yazılı Mesaj: Cep telefonu, PDA ( Kişisel dijital yardımcı) veya çağrı cihazı gibi bir cihaza k1sa yazılı mesajlar gönderilmesidir.

Fotoğraf / Video Klibi: İletişim araçlarıyla hazırlanan fotoğraf ve video kliplerinden oluşmaktadır.

Telefon: Sessiz veya devamlı aramalar, kötü niyetli mesajlar göndermektir. Kurbanı sorumlu göstermek amacıyla telefonu çalıp diğerlerini taciz etmekte kullanmak şeklinde de görülebilir.

E- posta: İletişim ağları üzerinden mesajların iletilmesi anlamına gelmektedir.

Sohbet Odası (chat): İki kullanıcı arasında bilgisayar aracılığıyla kurulan gerçek zamanlı bir iletişimdir.

Sosyal Paylaşım Siteleri: Bu siteler resimleri paylaşmak, taşımak ve eğlenmek için hızlı ve kolay bir yol sağlamaktadır. Ancak uygun güvenlik ayarları kullanılmadığında, dedikodu yaymak veya iftira amacıyla kötüye kullanılabilmektedir.

Anında Mesajlaşma: Başka bir bireyle özel bir sohbet odası yaratmaya olanak sağlayan bir iletişim servisidir.

Web Siteleri: Özel formatlı dokümanları destekleyen bir internet sağlayıcı sistemidir. 
Bloglar (Web günlüğü): Web siteleriyle forumların birleşmesinden oluşur, çevrimiçi kişisel günlükler olarak nitelendirilebilir.

Forumlar: herhangi bir konu ile ilgilenen insanların birbirleri ile o konu üzerinde tartışabildiği, fikir alışverişinde bulunabildiği, birbirlerinin sorunlarına çözüm önerileri sunabildikleri eş zamanlı olmayan iletişim ortamlarıdır.

Öğrencilerin siber zorbalığa ilişkin ifadelerine bakıldığında, gençler arasında siber zorbalığın yaşandığı ve bu yaşantılardan olumsuz etkilendikleri görülmektedir. Öğrencilerin gelişimsel olarak ergenlik döneminde bulunmaları bu olumsuz yaşantıların etkisini daha da artırmaktadır. Çünkü siber zorbalık sonucu gençlerin yaşadığı olumsuz duygu ve düşünceler, kimlik kazanma çabalarını ve sosyalleşme süreçlerini olumsuz etkilemektedir. Özellikle bu davranışlara maruz kalan gençlerin yaşadığı öfke, intikam, nefret ve aşağılanmışlık duygusu hem bireysel gelişimi hem de sosyal ilişkileri olumsuz yönde etkileyen duygulardır. Bu duyguları yaşayan gençler hem kendilerine hem de topluma yabancılaşmaya ve psikososyal problemleri yaşamaya yatkın olabilmektedirler. Kısaca siber zorbalık gençlerin sağlıklı gelişimlerini tehdit eden bir durumdur (Şahin, Sarı, Özer ve Er, 2010).

Literatürde gençleri siber zorbalık yapmaya iten nedenler şu şekilde sıralanmaktadır: Siber zorbalık araçlarıyla başkalarının üzerinde kontrol kurmayı amaçlama, saldırganca davranmaktan haz alma, arkadaşları arasında saygınlık kazanma çabası, gerçek yaşamda davranışa dökemediği saldırganlık içeren düşlemlerini sanal ortamda davranış olarak dile getirme arzusu, kendisine kötü davranan kişilerden sanal dünyada intikam almaya çalışma, sert ve soğukkanlı görünme isteği, siber zorbalıkta yakalanma ihtimalinin geleneksel akran zorbalığından daha zayıf olması, siber zorbalıkta kimliğini gizleme imkânının bulunması ve siber zorbalıkta mağdurla yüz yüze iletişim kurma zorunluluğunun bulunmaması (Eroğlu, 2011).Siber zorbalığın nedenlerinin sorulduğu bir araştırmaya göre, siber zorbaların \%38'i siber zorbalığın eğlence amaçlı olduğunu, \%25'i siber zorbalığın intikam alma amacı taşıdığını, \%6'sı bireyin kendisini kötü hissetmesinin siber zorbalık yapmasına yol açtığını ve \%31'i bu konuda herhangi bir fikrinin bulunmadığını belirtmiştir (Eroğlu 2011).

Diğer akran zorbalığı çeşitleriyle kıyaslandığında, gençlerin, siber zorbalıkla daha iç içe olduğu görülmektedir. Bunun sebebi, gençlerin siber zorbalığı zararsız, komik ve kabul edilir olarak görmesidir. Bu sebeple siber zorbalığa ilişkin duyarlılık oluşturmak ve konu ile ilgili bilinçlendirme çalışmaları yapmak büyük önem taşımaktadır (Türkkal, 2013).

Siber zorbalık hakkında duyarlılık oluşturmak için sunulan çalışmaların, siber zorbalık ortamını bütün kapsamlarıyla yansıtması gerekir. Belirli bir grubun sadece zorba ya da sadece kurban olarak algılanması, bilinçlendirme çalışmalarını etkisiz kılacaktır. Çünkü böyle bir durumda bireyler kendi davranışlarına dönüp bakmaktansa, olayı ötekileştirip dikkate almayacaktır. Öyleyse "siber zorbalık" ortamındaki farklı rolleri (kurban-mağdur) tanımlamak gerekir. Bu roller birbirinden yalıtarak sunulmamalıdır.

Farklı rollerin (kurban-mağdur) aynı kişide gözlemlendiği, kişinin yaptıklarıyla yüzleşme şansının olmadığı ve dolayısıyla duyarsızlaştığı, empati, pişmanlık gibi duyguların hissedilmesi olasılığının oldukça düşük olduğu siber zorbalık hakkında duyarlılık oluşturmak için kullanılacak en etkili yöntemlerden birinin yaratıcı drama olduğu düşünülmektedir. Yaratıcı drama, "doğaçlama, rol oynama vb tiyatro ya da drama tekniklerinden yararlanılarak bir grup çalışması içinde bireylerin, 
bir yaşantıyı, bir olayı, bir fikri, kimi zaman bir soyut kavramı ya da bir davranışı, eski bilişsel örüntülerinin yeniden gözden geçirildiği oyunsu süreçlerle anlamlandırılması ve canlandırılmasıdır" (San, 1996, s.149) şeklinde tanımlanmaktadır.

Yaratıcı drama süreçlerinde katılımcı bir durumun, çatışmanın içine girer, kurgusal gerçeklikte bu çatışmayı yaşar, grupla ve grup içi iletişimle irdelemeye başlar, dener, sorgular, yeniden analiz eder. Gerçekle kurgusal gerçeklik arasında özellikle drama tekniklerinin de yol göstermesiyle sürecin tam kendisi olur, onu yaşar ve bu sürecin devamını da belirler (Adıgüzel, 2006). Yaratıcı drama kişinin bireysel ve toplumsal sorunlar üzerinde düşünmesine yardımcı olur. Drama aracıllğıyla olaylar, durumlar ve bunların arasındaki bağlantılar kolaylıkla öğrenilebilir (Üstündağ, 2002). Bu açıdan bakıldığında yaratıcı dramanın kişiyi süreçte tutarak işlenen konu hakkında farkındalık oluşturmak için diğer yöntemlere göre daha etkili bir yöntem olduğu söylenebilir.

Yaratıcı dramanın sosyal becerilerin öğretiminde (Kara, Çam, 2007; Çalışkan Çoban, 2007, Akfirat, 2004; Buege, 1993; Freeman, Sullivan,ve Fulton, 2003), empati becerilerinin gelişiminde (Gökçearslan Çifci ve Altınova, 2014), özsaygı gelişiminde (Altınova, 2014) benlik kavramını geliştirmede (Erdoğan, 2006; McCaslin, 1990; Noble, Egan, ve McDowell, 1977), çatışma çözümü eğitiminde (Gündoğdu ve Izgar, 2010; Pipkin ve DiMenna, 1989, Gündoğdu, 2009), mesleki rehberlikte (Bozdoğan, 2003; Karataş ve Yavuzer, 2010), atılganlığı artırmada (Uşaklı, 2006), utangaçlığı azaltmada (Durmuş, 2006) etkili olduğu saptanmıştır. Yaratıcı drama yönteminin bireylerin sosyal gelişimine ve sosyalleşme düzeyine etkisini belirlemek için yapılan çalışmalar olduğu görülmektedir. Ancak uzun dönem verilen yaratıcı drama eğitiminin kişilerin sosyal sorun çözme becerilerine etkisini inceleyen bir çalışmaya rastlanmamıştır. Dolayısıyla yaratıcı dramanın sosyal sorun çözme becerisini arttıracağı umulmaktadır.

Yurt dışında yapılan araştırmalar incelendiğinde yaratıcı dramanın atılganlık düzeyine, yaratıcılığa, sosyal beceriye, problem çözme becerilerine, kendini ve diğerlerini tanımaya, empatiye, sosyal-duygusal gelişime olumlu yönde etkisi olduğu bunun yanında saldırganlık ve şiddet düzeylerinin azaltılmasında da etkisi olduğu görülmektedir (Bailey,1997; Danner, 2003'ten akt., Çalıskan-Çoban, 2007;Emunah, 1997; Fong, 2006; Jackson ve Bynum,1997; Pomerantz, 2003; Smeijsters ve Cleven, 2006; Taylor, 2000; Walsh-Bower ve Basso, 1999; Yassa, 1999).

\section{Araştırmanın Amacı}

$\mathrm{Bu}$ araştırma ile lise onuncu sınıf öğrencilerinde yaratıcı drama yöntemiyle siber zorbalık hakkında farkındalık oluşturulması amaçlanmıştır.

\section{Yöntem}

Araştırmada, deneysel modellerden "öntest-sontest kontrol gruplu model” (Karasar, 2000) kullanılmıştır. Bunun, deneysel işlemin bağımlı değişken üzerindeki etkisinin test edilmesiyle ilgili olarak araştırmacıya yüksek bir istatistiksel güç sağlayan, elde edilen bulguların neden sonuç bağlamında yorumlanmasına olanak veren ve davranış bilimlerinde sıklıkla kullanılan güçlü bir desen olduğu söylenebilir (Büyüköztürk, 2001: 27).

Araştırmanın bağımsız değişkeni "Yaratıcı Drama Programı”, bağımlı değişkeni de öğrencilerin "Siber Zorbalığa İlişkin Duyarlılık” dereceleridir.

Araştırmada kullanılan modelin simgesel görünümü Tablo (1)eede gösterilmektedir 
Tablo1. Araştırma Modeli

\begin{tabular}{|c|c|c|c|}
\hline Deney & Ön Testler & Deneysel İşlem & Son Testler \\
\hline Kontrol & Ön Testler & ------------------ & Son Testler \\
\hline
\end{tabular}

\section{Çalışma Grubu}

Araştırmanin çalışma grubunu, 2013-2014 öğretim yılı güz ve bahar döneminde Gaziçiftliği Anadolu Lisesi 10-F ve 10-D sınıfi öğrencileri oluşturmuştur. Deney grubunu 10-F sınıfi ve kontrol grubunu da 10-D sınıfı oluşturmuş̧tur. Deney grubu 16-17 yaş aralığında on erkek, altı kız toplam 16 öğrenciden oluşmaktadır. Dokuzuncu oturumda nakil gelen bir erkek öğrencinin de katılmasıyla son beş oturum on yedi kişi olarak yapılmıştır.

Kontrol grubunu 10-F sinıfiyla benzer özellikler gösteren 10-D sınıfı oluşturmuştur. On dokuz öğrencisi bulunan 10-D sınıfı, sekiz erkek ve on bir kız öğrenciden oluşmaktadır.

\section{İşlem}

Araştırmada öğrencilerin siber zorbalık hakkında duyarlılık oluşturması amaçlanmıştır. Çalışma, Gaziçiftliği Anadolu Lisesi onuncu sınıf öğrencileriyle Bilişim Teknolojileri ve İletişim dersi kapsamında, 2013-2014 eğitim öğretim yılında gerçekleştirilmiştir. Çalışma, haftada bir kez olmak üzere 13 hafta sürmüştür. Deney grubunda, öğretme durumları yaratıcı drama yöntemi esas alınarak planlanmış ve lider tarafından gerçekleştirilmiştir.

Atölyeler oluşturulurken grubun drama geçmişinin olmamasından dolayı ilk dört oturumda drama deneyimi kazandırmaya yönelik çalışmalar yapılmış, doğaçlamanın genel özellikleri ve ilkeleri işlenmeye çalışılmıştır.

Dördüncü oturumla birlikte siber zorbalığın işleneceği süreç başlatılmıştır. Dördüncü oturumun üçüncü etkinliğinde "okula nakil yoluyla gelen bir kız öğrenci”, altıncı oturumun dördüncü etkinliğinde "siber mağdur" olarak ilan edilmiştir. Oturumlarda siber zorbalığın tanımı, özellikleri, araçları, nedenleri işlenirken, içinde bulunulan durum, yaşantılar, yaşantıların yarattığ 1 sosyal ve psikolojik etkiler "siber mağdur" üzerinden ve birbiriyle bağlantılı olaylarla verilmeye çalışı1mıştır. Oturum başlıkları ve kazanım/lar aşağıda listelendiği şekildedir.

İlk dört oturum öğrencilerin yaratıcı dramaya alıştırmak, grupta iletişim, etkileşim, uyum güveni arttırmak amacıyla yapışmıştır.

\section{Oturum: İletişim ve Etkileşim}

Kazanım/lar: Arkadaşlarıyla iletişim kurar.

\section{Oturum: Uyum ve Güven}

Kazanım/lar: Grupla uyum içinde hareket eder.

Grup içinde birbirine güvenmenin önemini fark eder.

\section{Oturum: Doğaçlama ve Rol Oynama}

Kazanım/lar: İkili doğaçlama yapar.

Doğaçlama ilkelerini sıralar. 


\section{Oturum: Doğaçlama ve Rol Oynama}

Kazanım/lar: Grupla doğaçlama yapar.

Doğaçlamaların genel özelliklerini bilir.

\section{Oturum.: Zorbalıkla İlgili Kavramlar}

Kazanım/lar: Zorbalıkla ilgili kavramların farkına varır.

\section{Oturum: Siber Mağdurların Kișilik Özellikleri}

Kazanım/lar: Siber mağdurların kişilik özelliklerini sıralar.

\section{Oturum: Siber Zorbanın Kișilik Özellikleri}

Kazanım/lar: Siber zorbaların kişilik özelliklerini sıralar.

\section{Oturum: Siber Zorbalık ve Siber Zorbalığın Özellikler}

Kazanım/lar: Siber zorbalığı tanımlar.

Siber zorbalığın özelliklerini bilir.

Siber zorbalığın görülme biçimlerini sıralar.

\section{Oturum: Siber Zorbalığa Maruz Kalmanın Mağdur Üzerindeki Psikolojik Etkileri}

Kazanım/lar: Siber zorbalığa maruz kalmanın mağdur üzerindeki psikolojik etkilerini fark eder.

10. Oturum: Siber Zorbalığa Maruz Kalmanın, Mağdurun Aile İçindeki ve Okuldaki İlişkilerine Etkisi

Kazanım/lar: Siber zorbalığa maruz kalmanın, aile içindeki ilişkilere etkisini fark eder.

\section{Oturum: Siber Zorbalığın Nedenleri}

Kazanım/lar: Siber zorbalığın nedenlerini sıralar.

\section{Oturum: Siber Zorbalıktan Korunma Yolları}

Kazanım/lar: Siber zorbalıktan korunma yollarını sıralar.

\section{Oturum: Siber Zorbalığa Maruz Kalan Kişiye Yaklaşım}

Kazanım/lar: Siber zorbalığa maruz kalan kişiye nasıl yaklaşılması gerektiğini bilir.

\section{Veri Toplama Araçları}

Araştırmanın amacı doğrultusunda Arıcak, Kınay ve Tanrıkulu tarafından (2013) yılında geliştirilen Siber Zorbalığa İlişkin Duyarlılık Ölçeği (SBDÖ) kullanılmıştır.

\section{Siber Zorbalığa İlişkin Duyarlılık Ölçeği (SBDÖ)}

Ölçeğin geçerlik ve güvenirlik çalışması İstanbul ilinde öğrenim gören 663 lise öğrencisi üzerinde yapılmıştır.

Ölçek üzerinde yapılan açımlayıcı faktör analizinde tek faktörlü ve bu tek faktör altında toplam varyansın $\% 46.65$ 'ini açıklayan bir yapı ortaya çıkmıştır. Ortaya çıkan bu yapı için doğrulayıcı faktör analizi yapılmış ve uyum değerlerinin modeli doğruladığg görülmüştür (Ki-kare $\chi^{2} / \mathrm{sd}=3,220$, RMSEA= .082). Ölçeğin iç tutarlılık katsayıları .83 ile .90 , iki yarı test- güvenirlik katsayıları .75 ile .84 arasında, bulunmuştur. Ayrıca ölçeğin madde-toplam korelasyonlarının tümleşik grup için .42 ile .63 arasında sıralandığı ve \%27'lik alt-üst grupların ortalamaları arasındaki tüm farkların anlamlı 
olduğu bulunmuştur. Bu sonuçlara göre ölçeğin geçerli ve güvenilir bir ölçme aracı olduğu yargısına varılmıştır (Tanrıkulu, Kınay ve Arıcak, 2013).

Ölçek, üçlü (Evet, Bazen, Hayır) cevap ölçeği üzerinden yanıtlanmaktadır. Ölçeğin puanlanması, hayır=1, bazen=2 ve evet=3 şeklindedir. Ölçekten alınan puanın yüksekliği siber zorbalığa ilişkin duyarlılığın yüksek oluşunu göstermektedir (Tanrıkulu, Kınay ve Arıcak, 2013).

\section{Verilerin Toplanması ve Analizi}

"Siber Zorbalığa İlişkin Duyarlılık Ölçeği (SBDÖ) öntest sontest uygulamalarının ardından, elde edilen veriler SPSS 18.0 istatistik programında analiz edilmiştir. Ölçeğin ön test, son testlerinin aritmetik ortalamaları ve standart sapmaları hesaplanmıştır. Deney ve kontrol grubuna alınan öğrencilerin Siber Zorbalığa İlişkin Duyarlılık Ölçeği’nden (SBDÖ) aldıkları puanlar deney ve kontrol grubu, ön ve son ölçümler bakımından karşılaştırılmasında Mann-Whıtney U testinden yararlanılmıştır. Uygulama öncesi ve sonrasında öğrencilerin siber zorbalığa ilişkin duyarlılıklarında meydana gelen değişimin karşılaştırılması için Wilcoxon Sıralı İşaretler Testi uygulanmıştır(Siegel, 1977).

\section{Bulgular}

Bu kısımda, öğrencilerin Siber Zorbalığa İlişkin Duyarlılık Ölçeği'nden (SBDÖ) aldıkları puanlar sonucunda ulaşılan bulgular yer almaktadır.

Tablo 2. Deney ve Kontrol Gruplarına Uygulanan Siber Zorbalı̆̆a İlişkin Duyarlılık Ölçeğinden Elde Edilen Verilerin Betimsel İstatistikleri

\begin{tabular}{|c|c|c|c|c|c|c|c|}
\hline \multirow{2}{*}{ Gruplar } & \multirow{2}{*}{$\mathbf{N}$} & \multicolumn{2}{|c|}{ Ön uygulama } & \multicolumn{2}{c|}{ Son uygulama } & \multicolumn{2}{c|}{ Fark(sontest-öntest) } \\
\cline { 3 - 8 } & & $\bar{X}$ & ss & $\bar{X}$ & ss & $\bar{X}$ & ss \\
\hline Deney & 16 & 30,06 & 4,79 & 34,81 & 3,79 & $-4,75$ & 2,48 \\
\hline Kontrol & 19 & 31,00 & 3,63 & 31,36 & 3,86 &,- 36 & 3,68 \\
\hline
\end{tabular}

Tablo 3'de görüldüğü gibi siber zorbalığa ilişkin duyarlılık ölçeğinden ön uygulaması sonucunda deney 30,06 kontrol grubu ise 31,00 ortalamaya ulaşmıştır. Çalışma sonucunda ise deney grubu 34,81 kontrol grubu ise 31, 36 ortalama puan almıştır. Siber zorbalığa ilişkin duyarlılık ölçeği puanlarının son test ön test arasındaki farklılıklara bakıldığında; deney grubunda 4,75 puanlık bir artış olurken, kontrol grubunda ise 0,36 puanlık bir artış görülmüştür.

Deney grubunda yapılan drama çalışmasının öğrencilerin siber zorbalığa ilişkin duyarlılık puanlarını arttırdığı görülmektedir. Bu farklılıkların istatistiksel olarak anlamlı olup olmadığına ilişkin karşılaştırmalı istatistikler sırayla aşağıda verilmiştir. Deney ve kontrol gruplarının karşılaştırılmasında anlamlılık düzeyi 0,05 olarak belirlenmiştir.

Deney ve kontrol grubunun siber zorbalığa ilişkin duyarlılık ölçeğinden aldığı puanların ön testinin birbirinden anlamlı derecede farklılaşıp farklılaşmadığını belirlemek için bağımsız örneklemler arası Mann-Whitney U testi yapılmıştır. Yapılan bu karşılaştırmada elde edilen bulgular Tablo 4'de verilmiştir. 
Tablo 3. Deney ve Kontrol Gruplarının Ön Test Puanlarının Karşılaştırılması

\begin{tabular}{|c|c|c|c|c|c|c|}
\hline Gruplar & Ölçümler & $\mathrm{n}$ & $\bar{X}$ & SS & $\mathrm{z}$ & $\mathrm{p}$ \\
\hline Deney & \multirow{2}{*}{ Öntest } & 16 & 30,06 & 4,79 & \multirow{2}{*}{,- 632} & \multirow{2}{*}{, 528} \\
\hline Kontrol & & 19 & 31,00 & 3,63 & & \\
\hline Deney & \multirow{2}{*}{ Sontest } & 16 & 34,81 & 3,79 & \multirow{2}{*}{$-2,359$} & \multirow{2}{*}{,018 } \\
\hline Kontrol & & 19 & 31,36 & 3,86 & & \\
\hline
\end{tabular}

Tablo 4 incelendiğinde deney ve kontrol grubu öğrencilerinin ön test puan ortalamalar1 arasında istatistiksel olarak anlamlı farkın olmadığı görülmüştür ( $>0,05)$. Tablo 4 son testler bakımından incelendiğinde deney ve kontrol grubu öğrencilerinin son test puan ortalamaları arasında istatistiksel olarak anlamlı farkın olduğu görülmüştür $(p<0,05)$. Bir başka ifadeyle deney ve kontrol grubu öğrencilerinin drama çalışması sonrasında farklılaştı̆̆ söylenebilir.

Deney grubunun siber zorbalığa ilişkin duyarlılıklarının ön ve son test puanları arasındaki farkın anlamlılığı için bağımlı örneklemler arası Wilconson testi kullanılmıştır. Karşılaştırma sonunda elde edilen bulgular Tablo 5'de verilmiştir.

Tablo 4. Deney grubunun öntest -sontest puanlarının karşılaştırılması

\begin{tabular}{|c|c|c|c|c|c|c|}
\hline Gruplar & Ölçümler & $\mathrm{n}$ & $\bar{X}$ & ss & z & $\mathrm{p}$ \\
\hline \multirow{2}{*}{ Deney } & Öntest & 16 & 30,06 & 4,79 & \multirow{2}{*}{$-3,425 a$} & \multirow{2}{*}{, 001} \\
\hline & Sontest & 16 & 34,81 & 3,79 & & \\
\hline \multirow{2}{*}{ Kontrol } & Öntest & 19 & 31,00 & 3,63 & \multirow{2}{*}{,$- 476 \mathrm{a}$} & \multirow{2}{*}{,634 } \\
\hline & Sontest & 19 & 31,36 & 3,86 & & \\
\hline
\end{tabular}

Tablo 5'de görüldüğü gibi deney grubu ön uygulamada 30,06 olan puan ortalaması uygulama sonrasında 4,75 puan artmıştır. Öğrencilerin ön test ve son test siber zorbalığa ilişkin duyarlılık ölçeği puan ortalamaları arasında son test lehine istatistiksel olarak anlamlı fark bulunmuştur $(\mathrm{p}<0,05)$. Bu durum yapılan drama çalışmasının, öğrencilerin siber zorbalığa ilişkin duyarlılıklarını arttırdığını göstermektedir.

Tablo 5'de görüldüğü gibi kontrol grubu ön uygulamada 31,00 olan puan ortalamas1, uygulama sonrasında 31,36'ya çıkmıştır. Öğrencilerin ön test ve son test siber zorbalığa ilişkin duyarlılık puan ortalamaları arasında son test lehine istatistiksel olarak anlamlı fark bulunmamıştır $(\mathrm{p}>0,05) . \mathrm{Bu}$ durum grup çalışmasına katılmayan öğrencilerin siber zorbalığa ilişkin duyarlılık düzeylerinin aynı kaldığını göstermektedir.

Deney ve kontrol grubunun siber zorbalığa ilişkin duyarlılık son test-ön test puanları arasındaki fark ortalamalarının birbirinden anlamlı derecede farklılaşıp farklılaşmadığını belirlemek için bağımsız örneklemler arası Mann-Whitney U testi yapılmıştır. Yapılan bu karşılaştırmadan elde edilen bulgular Tablo 6'da verilmiştir. 
Tablo 5. Deney ve Kontrol Grubunun Siber Zorbalı̆̆a İlişkin Duyarlılı Son-Ön Test Puanları Arasındaki Farkın Karşılaştırılması

\begin{tabular}{|c|c|c|c|c|c|}
\hline Gruplar & $\mathrm{n}$ & Fark $\bar{X}$ & ss & z & $\mathrm{p}$ \\
\cline { 1 - 3 } Deney & 16 & 4,75 & 2,48 & \multirow{2}{*}{$-3,316$} & \multirow{2}{*}{, 001} \\
\cline { 1 - 3 } Kontrol & 19 &, 36 & 3,68 & & \\
\hline
\end{tabular}

Tablo 6'da görüldüğü gibi siber zorbalığa ilişkin duyarlılık puanları arası fark deney grubunda 4,75 iken kontrol grubunda ,36 olarak belirlenmiştir. Karşılaştırma sonunda siber zorbalığa ilişkin duyarlılık ölçeği puanları arasındaki farkın istatistiksel olarak deney grubu lehine anlamlı olduğu gözlenmiştir $(\mathrm{p}<0,05)$.

\section{Sonuç}

$\mathrm{Bu}$ araştırmada, lise öğrencilerinin siber zorbalık hakkındaki duyarlılıkları sorgulanmıştır. $\mathrm{Bu}$ amaçla deney grubu ve kontrol grubu oluşturulmuştur. Deney grubuyla 13 oturumdan oluşan siber zorbalık hakkında duyarlılık oluşturmaya dayalı yaratıcı drama çalışması yapılmıştır. Kontrol grubuna ise herhangi bir işlem uygulanmamıştır. Ön-test, son-test ölçümlerinden elde edilen değerlere uygulanan istatistiksel analizler sonucunda, yapılan drama çalışmasının öğrencilerin siber zorbalık hakkındaki duyarlılıklarını arttırmada etkili olduğu görülmüştür. Siber zorbalık son yıllarda araştırılmaya başlanmış bir konu olmasına rağmen teknolojik gelişmelerin hızla artmasıyla birlikte ilerleyen yıllarda geleneksel zorbalık kadar önemli bir sorun haline geleceği yapılan araştırmalar göstermektedir (Ayas ve Horzum, 2012). Bu çalışmayla ergenin siber zorbalık hakkında bilgi sahibi olması ve siber zorbalığa ilişkin duyarlılık oluşturması, kendisini siber zorbalıktan koruması ve siber zorba davranışlar sergilememesi için önemli bir adımdır.

Aşağıda elde edilen bulgulardan yola çıkarak ileride yapılacak çalışmalara 1şık tutabilecek ve alanda çalışan eğitimcilere ve diğer uzmanlara yardımcı olabilecek önerilere yer verilmiştir.

Öğrencilerle yapılacak siber zorbalıkla ilgili duyarlılık geliştirme çalışmalarının daha etkili olabilmesi için uzun süreli çalışmaların yapılmasının önemli olduğu düşünülmektedir.

$\mathrm{Bu}$ araştırma çalışmasının ilköğretim öğrencileriyle de gerçekleştirilmesi, ilköğretim öğrencilerinde de siber zorbalığa ilişkin duyarlılık oluşturmak açısından önemli bir adım olacaktır. Böyle bir çalışma öncesinde araştırmadeki oturumların gözden geçirilmesi ve çalışılacak yaş grubuna uyarlanması yerinde olacaktır.

Yaratıcı drama çalışmalarının daha sağlıklı bir şekilde sürdürülebilmesi, grup içindeki etkileşimin daha fazla olabilmesi ve gruptan ayrılmalar nedeniyle yaşanan olumsuzluklardan daha az etkilenilmesi amacıyla katılımcı sayısına ve devam durumlarına özen gösterilmelidir.

\section{Kaynakça}

Adıgüzel, Ö. (2012). Eğitimde yaratıcı drama. Naturel Yayıncılık.

Adıgüzel, Ö. (2006). Yaratıcı drama kavramı, bileşenleri ve aşamaları. Yaratıcı Drama Dergisi, 1 (1), 17-30.

Adıgüzel, Ö. (2010). ( Ed. ). Yaratıcı drama 1999-2002 yazılar. Naturel Yayınları, Ankara.

Aktepe, E. (2013). Ergenlerde siber zorbalık ve siber mağduriyet. In Yeni Symposium , 51(1). 
Arda, I. ve Levent, S. (2004). Her güne bir oyun. İstanbul: Yapı Kredi Yayınlart.

Arıcak, O. T. (2011). Siber zorbalık: Gençlerimizi bekleyen yeni tehlike, Kariyer Penceresi. 2(6), 10-12.

Arıcak, O. T. , Kınay, H. , ve Tanrıkulu, T. (2011). Siber zorbalığa ilişkin duyarlılık ölçeği. Trakya Üniversitesi Eğitim Fakültesi Dergisi. 3(1), 38-47.

Ayas T., Horzum, M.B. (2012). İlköğretim öğrencilerinin sanal zorba ve mağdur olma durumu. Elementary Education Online, 11(2), 369-380.

Bamford, A. (2004). Cyber-bullying. In AHISA Pastoral Care National Conference, Melbourne.

Bauman, S. (2007). Cyberbullying: a virtual menace. In National Coalition Against Bullying National Conference.

Belsey, B. (2005). Cyberbullying: An emerging threat to the "always on" generation. Recuperado el, 5.

Beran, T., ve Li, Q. (2008). The relationship between cyberbullying and school bullying. The Journal of Student Wellbeing, 1(2), 16-33.

Dökmen, Ü. (1998). İletişim çatışmaları ve empati (8.bs.). İstanbul: Sistem Yayınc1lık.

Eroğlu, Y. (2011). Koşullu öz-değer, riskli internet davranışları, internet kullanım sıklı̆̆ ve siber zorbalık arasindaki ilişkinin incelenmesi. Yüksek lisans tezi, Sakarya Üniversitesi Eğitim Bilimleri Enstitüsü Eğitimde Psikolojik Hizmetler Bilim Dalı.

Eroğlu, Y. ve Peker, A. (2011). Aileden ve arkadaştan algılanan sosyal destek ve siber mağduriyet: Yapısal eşitlik modeliyle bir inceleme. Akademik Bakış Dergisi, 27, 1-20.

Hinduja, S., \& Patchin, J. W. (2010). Bullying, cyberbullying, and suicide. Archives of Suicide Research, 14(3), 206-221.

Hines, H. N. (2011). Traditional bullying and cyber-bullying: are the impacts on self-concept the same?. Doctoral dissertation, Western Carolina University.

Hürriyet Planet. http://www.hurriyet.com.tr/planet/19693094.asp, Türk kızı Şeniz sanal zorba kurbanı(Erişim tarihi 20.10.2013)

Kowalski, R. M. , \& Limber, S. P. (2007). Electronic bullying among middle school students. Journal Of Adolescent Health, 41(6), 22-30.

Özdemir, M., ve Akar, F. (2011). Lise öğrencilerinin siber-zorbalığa ilişkin görüşlerinin bazı değişkenler bakımından incelenmesi. Kuram ve Uygulamada Eğitim Yönetimi Dergisi, 17(4), 605-626.

Rogers, V. (2010). Cyberbullying: Activities to help children and teens to stay safe in a texting, twittering, social networking world. Jessica Kingsley Publishers.

San, İ. (1998). Yaratıcı drama çalışmalarının dünü ve bugünü. 2. Ulusal Çocuk Kültürü Kongresi. Ankara.

Serin, H. (2012). Ergenlerde siber zorbalık / siber mağduriyet yaşantıları ve bu davranışlara ilişkin öğretmen ve eğitim yöneticilerinin görüşleri. Yayımlanmamış, doktora tezi, İstanbul Üniversitesi, İstanbul.

Şahin, M. , Sarı, S. V. , Özer, Ö. , ve Er, S. H. (2010). Lise öğrencilerinin siber zorba davranışlarda bulunma ve maruz kalma durumlarına ilişkin görüşleri. Sdü Fen Edebiyat Fakültesi Sosyal Bilimler Dergisi, 21, 257-270.

Smith, P. K. , Mahdavi, J. , Carvalho, M., \& Tippett, N. (2006). An investigation into cyberbullying, its forms, awareness and impact, and the relationship between age and gender in cyberbullying. Research Brief No. RBX03-06. London: DfES.

Türkkal, Ş. (2013). Siber zorbalık. Poli Dergisi.

Üstündağ, T. (2002). Yaratıcı drama öğretmenimin günlüğ̈̈̈. Ankara: Pegem A Yayıncılık.

Wikipedia katılımcıları (2010). Siber. Vikipedi, özgür ansiklopedi. url://tr.wikipedia.org/w/index.php?title=siber\&oldid $=8138150$ (Erişim tarihi 19.04.2014)

Willard, N. (2005). Educator's guide to cyberbullying addressing the harm caused by online social cruelty. Retrieved July, 19. http://www.asdk12.org/MiddleLink/AVB/bully_topics/EducatorsGuide_Cyberbullying.pdf

Willard, N. E. (2007). Cyberbullying and cyberthreats: Responding to the challenge of online social aggression, threats, and distress. Research Press.

Yaman, E. , Eroğlu, Y., ve Peker, A. (2011). Okul zorbalı̆̆ ve siber zorbalık. İstanbul: Kaknüs Yayınlarl. 
